MIKROELEKTRONIKA

\title{
Adaptive Thermo-Compensation of Magneto-Resistive Sensor
}

\author{
V. Markevicius, D. Navikas \\ Department of Electronics Engineering, Kaunas University of Technology, \\ Studentustr.50,LT-51424 Kaunas, phone: +37037300522,e-mail: dangirutis.navikas@ktu.lt \\ crossref $\mathrm{http}: / / \mathrm{dx}$.doi.org/10.5755/j01.eee.114.8.694
}

\section{Introduction}

Anisotropic Magnetoresistance occurs in certain ferrous materials and can be applied as a thin strip to become a resistive element. Permalloy is used to form four resistive elements to become a wheatstone bridge sensor. Each magneto-resistive strip element possesses an ability to change resistance in relationship where $(\theta)$ is the angle between the magnetic moment $(\mathrm{M})$ vector and the current flow (I) (Fig.1) [1].

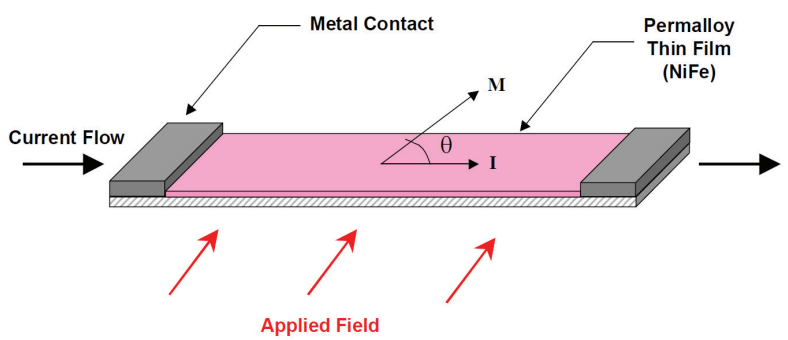

Fig. 1. AMR Element [1]

To create the sensor from the AMR elements, the four elements are oriented in a diamond shape with the ends connected together by metallization to form the wheatstone bridge $[1,2]$. It should be noted that some errors should be adjusted to enhance the accuracies of the measurements. The first one is the offset error voltage. To compensate for the offset, either analog signal processing or digital value corrections can be used.

Another common error to be accounted for is the drift in the material constant versus temperature. This error effects both the bridges sensitivity and offset. Coefficients of temperature (tempcos) of the sensitivity and offset are nominally $-0.32 \% /{ }^{\circ} \mathrm{C}$ and $-0.01 \% /{ }^{\circ} \mathrm{C}$ respectively $[1,2]$.

In real systems heating or cooling effects on sensor bridge offset are detected and must be corrected. Fig. 2 shows the typical scenario, the AMR sensor is installed outdoor and is affected by the Earth magnetic field only. If application should have a large operating temperature range (case of outdoor installation $-30+70{ }^{\circ} \mathrm{C}$ or more), thermo-compensation technique should be implemented to the application. Francesco Battini and others [3] propose to use preliminary calibration and temperature compensation.

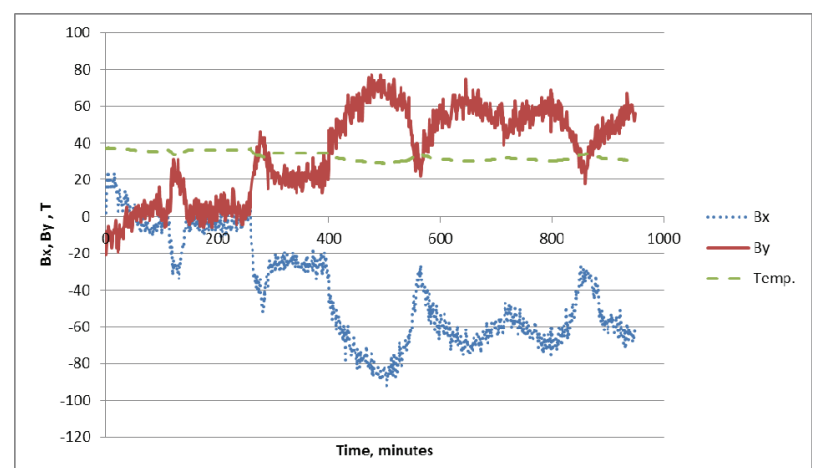

Fig. 2. Outdoor sensor thermal falsing effects during one week

Because studies of the temperature influences on the whole system showed an almost linear trend of offset and gain over temperature. Xisheng Li and others [4], for offset elimination and bridge sensitivity determination, proposed use of four step measurement using SET/RESET pulses. Sensor flipping to eliminate offset errors is proposed in paper [5].

There are several manufacturers producing AMR sensors. In order to determine which thermo-compensating technique should be used in applications, some experiments were carried out.

\section{Experimental investigation}

For experimental investigation were chosen three different AMR sensors (Honeywell HMC1022, MEMSIC MMC314xMS and STMicroelectronics LSM303DLH). Experiments were performed using data acquisition device (based on MSP430F5438 microcontroller) and personal computer. Structure scheme of the experiment is shown on Fig. 3.

AMR sensors HMC1022 and MMC314xMS were placed in the thermo-chamber and temperature ranged from $-19{ }^{\circ} \mathrm{C}$ to $57{ }^{\circ} \mathrm{C}$ (HMC1022 case) and from $-26{ }^{\circ} \mathrm{C}$ to $68^{\circ} \mathrm{C}$. Magnetic induction components values were 
recorded to file. Experiment results are presented in Fig. 4 and Fig. 5.

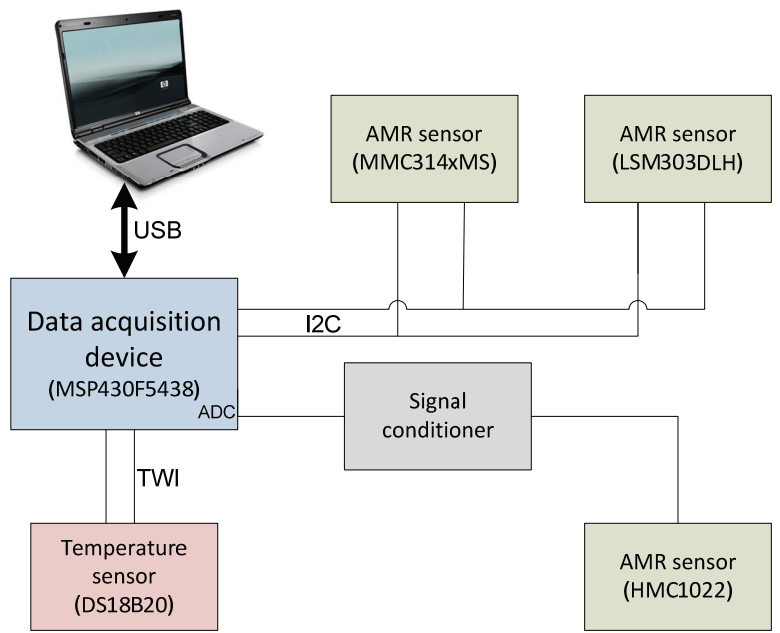

Fig. 3. Structure scheme of experiment

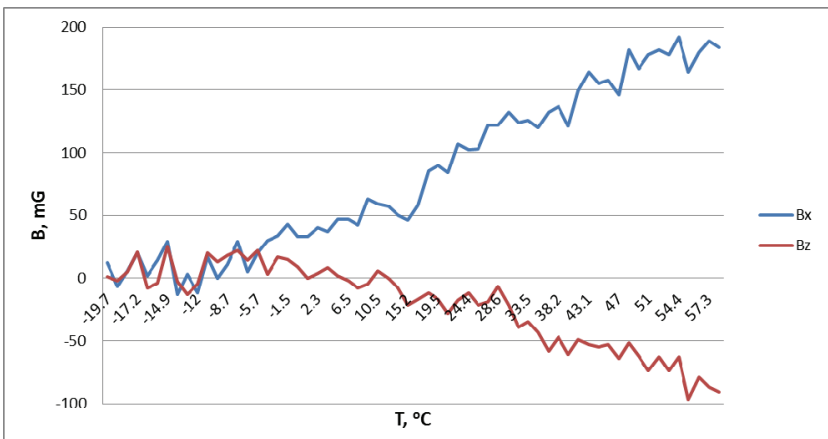

Fig. 4. Magnetic induction versus temperature (HMC1022)

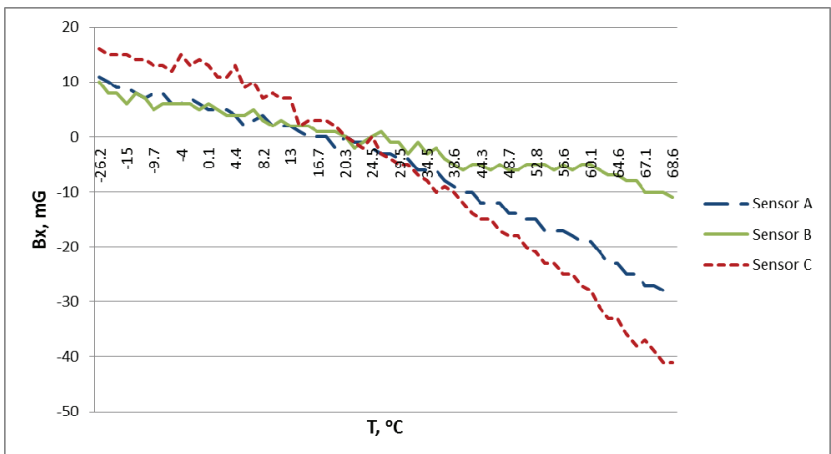

Fig. 5. Magnetic induction component $B_{x}$ versus temperature (MMC314xMS)

Can be seen that data is noisy and magnetic induction values are reduced, because the Earth magnetic field is inhibited and distorted by thermo-chamber iron alloy corps.

Magnetic induction components dependencies from temperature are exactly linear and differ from sensor to sensor.

Another experiment was carried out with six LSM303DLH sensors. Sensors were placed outdoors in fixed positions. The experiment lasted for 6 months under various conditions. The results were stored in the various periods of time and values were averaged. In Fig. 6 and Fig. 7 are shown magnetic induction components dependencies from temperature of $2^{\text {nd }}$ and $5^{\text {th }}$ sensors.

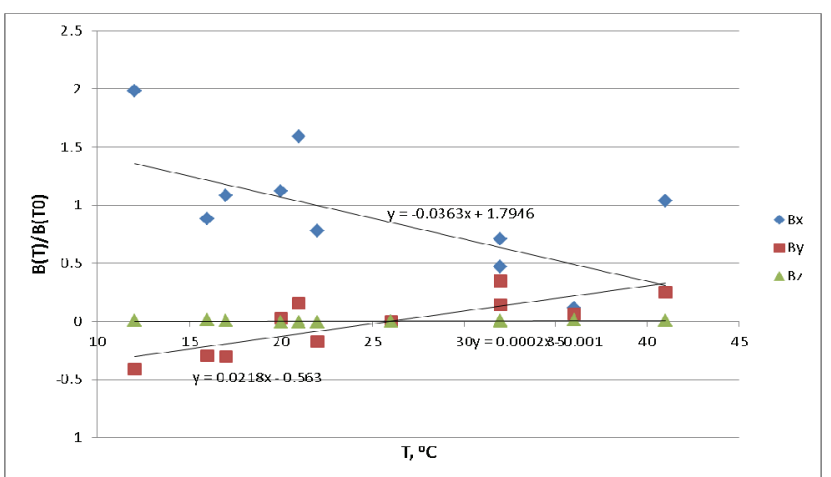

Fig. 6. Magnetic induction components $B_{x}, B_{x}, B_{x}$ versus temperature $\left(2^{\text {nd }}\right.$ sensor LSM303DLH)

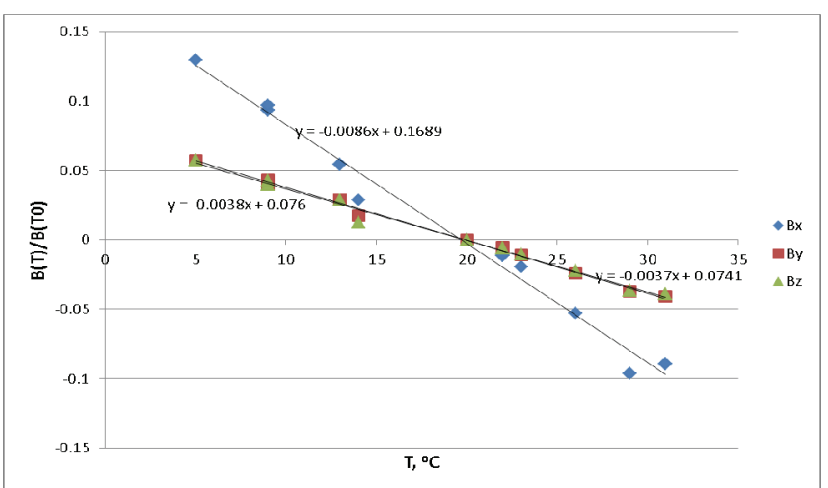

Fig. 7. Magnetic induction components $B_{x}, B_{x}, B_{x}$ versus temperature $\left(5^{\text {th }}\right.$ sensor LSM303DLH)

The figures show that temperature coefficients are different and even have the opposite sign. Coefficients of other sensors have the same sign, but values are different.

Generalized magnetic inductions components trendlines (normalized on $30^{\circ} \mathrm{C}$ ) of all six sensors are presented in Fig.8-Fig. 10.

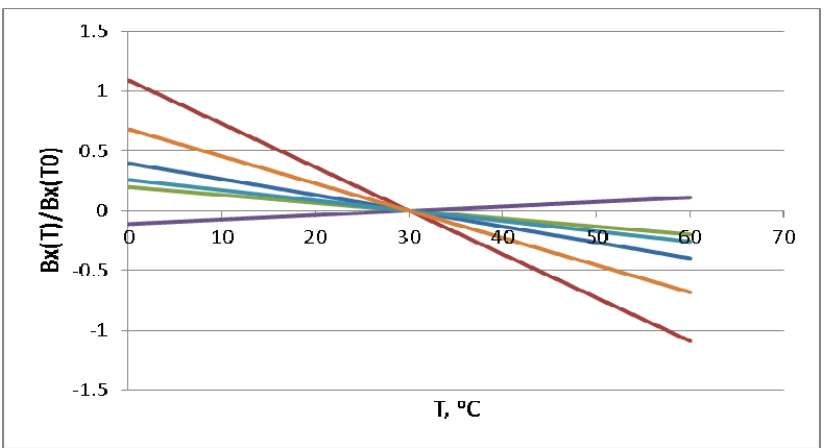

Fig. 8. Magnetic induction component $B_{x}$ versus temperature (six LSM303DLH sensors)

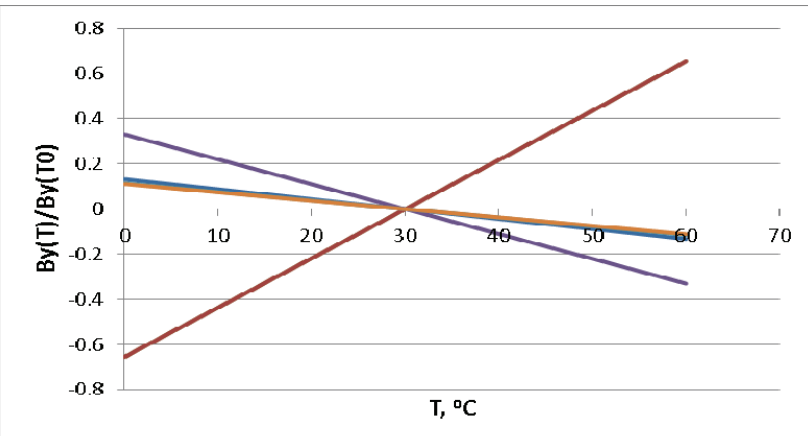

Fig. 9. Magnetic induction component $\mathrm{B}_{\mathrm{y}}$ versus temperature (six LSM303DLH sensors) 


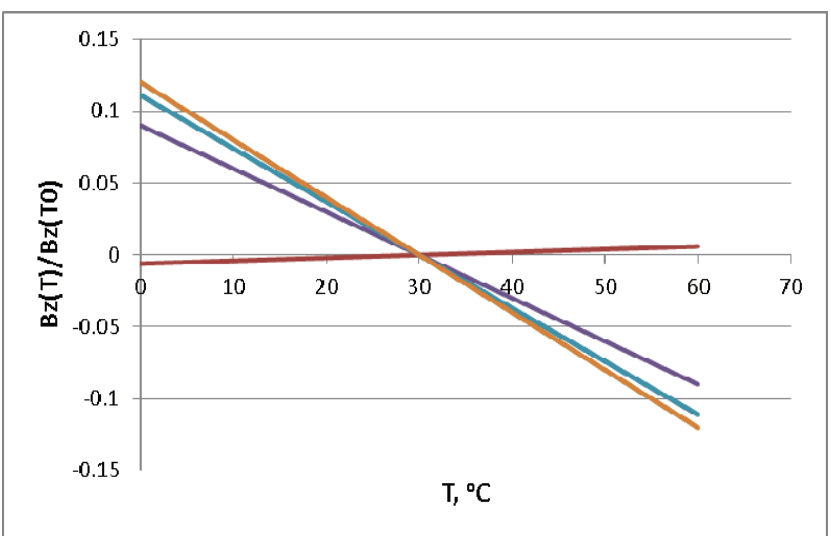

Fig. 10. Magnetic induction component $B_{z}$ versus temperature (six LSM303DLH sensors)

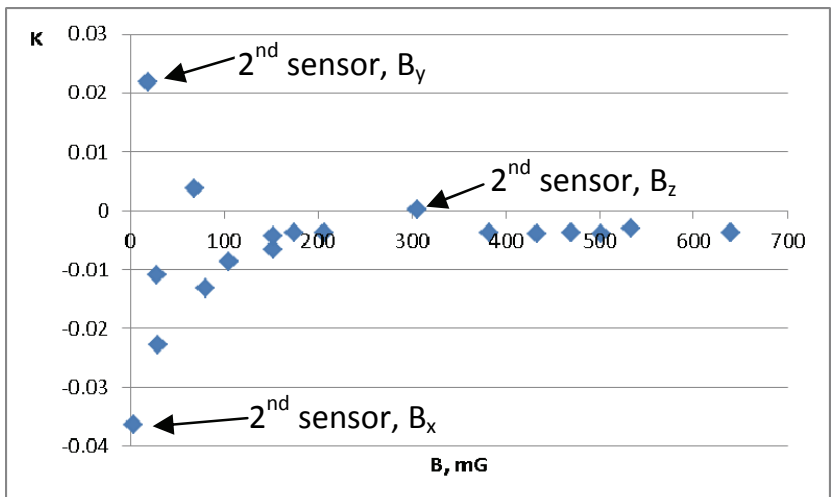

Fig. 11. Linear approximation coefficient versus magnetic induction

The figures show that most of the sensors have similar coefficient. However, some sensors have coefficients of induction components which differ significantly from each other. $2^{\text {nd }}$ sensor characteristics are especially exclusive.

During the experiment it has been noticed, that Sensor temperature stability depends on the magnetic field strength.

Evaluating the results we can conclude that, in order to ensure a stable job of application, sensors should be classified according to temperature coefficients and then permanent coefficients can be used. Other possibility is implementation of adaptive thermo-compensation.

\section{Adaptive thermo-compensation}

Adaptive thermo-compensation algorithm can be implemented if the AMR sensor is connected to a controller that controls the ambient temperature and magnetic field values in separate directions.

Solution to the problem compounded by the fact that after the installation of sensors and power-up they must begin to function immediately. Sensors have to set coefficients "free" from work.

The coefficients determination was implemented and investigated using two methods:

- Linear interpolation between two furthest points of temperature variation line;
- Linear approximation using the least square method.

Coefficients of linear interpolation:

$$
\begin{gathered}
K_{x}=\frac{H_{x \max }-H_{x \min }}{T_{\text {max }}-T_{\text {min }}}, \\
K_{y}=\frac{H_{y \text { max }}-H_{y \text { min }}}{T_{\text {max }}-T_{\text {min }}}, \\
K_{z}=\frac{H_{z \text { max }}-H_{z \text { min }}}{T_{\text {max }}-T_{\text {min }}}
\end{gathered}
$$

and interpolated magnetic induction values:

$$
\begin{aligned}
& H_{x}^{*}=H_{x 0}+T K_{x}, \\
& H_{y}^{*}=H_{y 0}+T K_{y}, \\
& H_{z}^{*}=H_{z 0}+T K_{z} .
\end{aligned}
$$

That linear interpolation could be realized in a simple 8 bits microcontroller. There is no need for a large amount of memory and CPU speed.

For linear approximation using the least squares method equation systems were created:

$$
\begin{gathered}
\left\{\begin{array}{c}
(n+1) a_{0 X}+\left(\sum_{i=0}^{n} T_{i}\right) a_{1 X}=\sum_{i=0}^{n} H x_{i}, \\
\left(\sum_{i=0}^{n} T_{i}\right) a_{0 X}+\left(\sum_{i=0}^{n} T_{i}^{2}\right) a_{1 X}=\sum_{i=0}^{n} H x_{i} T_{i},
\end{array}\right. \\
P_{1 X}(T)=a_{0 X}+a_{1 X} T, \\
\left\{\begin{array}{c}
(n+1) a_{0 X}+\left(\sum_{i=0}^{n} T_{i}\right) a_{1 X}=\sum_{i=0}^{n} H x_{i}, \\
\left(\sum_{i=0}^{n} T_{i}\right) a_{0 X}+\left(\sum_{i=0}^{n} T_{i}^{2}\right) a_{1 X}=\sum_{i=0}^{n} H x_{i} T_{i},
\end{array}\right. \\
\left\{\begin{array}{c}
P_{1 X}(T)=a_{0 X}+a_{1 X} T, \\
(n+1) a_{0 Y}+\left(\sum_{i=0}^{n} T_{i}\right) a_{1 Y}=\sum_{i=0}^{n} H y_{i}, \\
\left(\sum_{i=0}^{n} T_{i}\right) a_{0 Y}+\left(\sum_{i=0}^{n} T_{i}^{2}\right) a_{1 Y}=\sum_{i=0}^{n} H y_{i} T_{i}, \\
P_{1 Y}(T)=a_{0 Y}+a_{1 Y} T .
\end{array}\right.
\end{gathered}
$$

For linear approximation using least squares method should be used 16 bits microcontroller and more memory and other recourses in comparison with linear interpolation method.

The algorithm of adaptive thermo-compensation is shown in Fig. 12. In order to determine the number of points when starting to use renewed coefficients for magnetic induction values correction experiment with LSM303DLH sensor was caried out. Coefficients were calculated every one degree, results are shown in Fig. 13. 


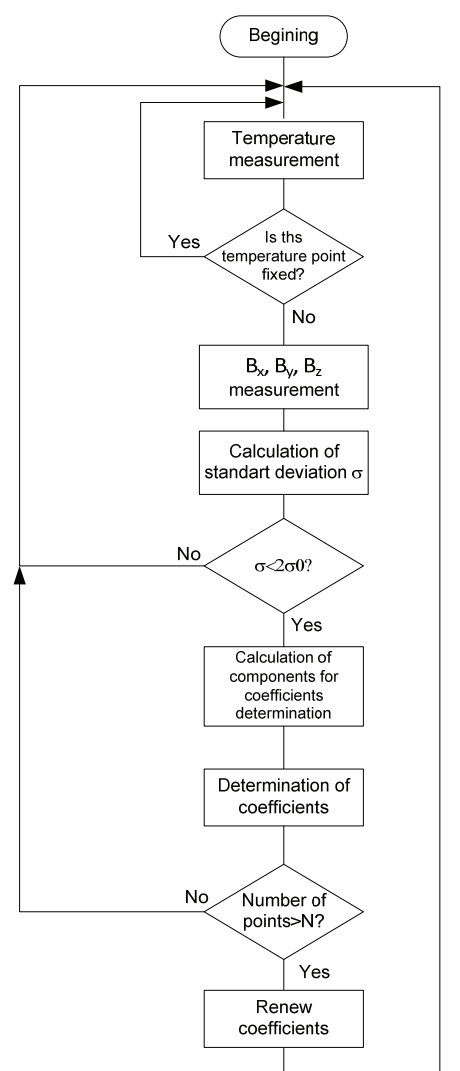

Fig. 12. Algorithm of adaptive thermo-compensation

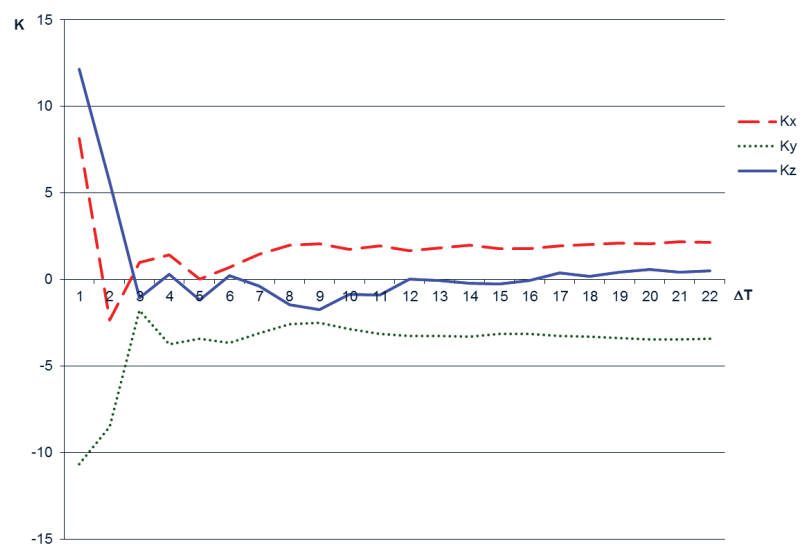

Fig. 13. Linear approximation coefficient versus temperature interval
It shows that using least square method renewed coefficients can be used after small temperature changes (4-6 degrees). When temperature interval is more than 10 degrees, coefficients values stabilize and stay almost unchanged.

\section{Conclusions}

1. Sensor temperature stability depends on the magnetic field strength components and sensor manufacturing process errors.

2. AMR sensors temperature coefficients are different and may even have the opposite sign.

3. To ensure sufficient accuracy of magnetic field measurement, adaptive temperature compensation must be implemented.

4. Complex, but more effective adaptive determination of the temperature dependence coefficients using the least-squares method.

5. Sensors with adaptive thermo-compensation do not require additional calibration before installation.

\section{References}

1. Honeywell. Applications of Magnetic Position Sensors. Online: http://www51.honeywell.com/aero/common/docume nts/Applications-of-Magnetic-Position-Sensors.pdf.

2. Honeywell. AN212 Handling Sensor Bridge Offset. Online: http://www51.honeywell.com/aero/common/documents/myae rospacecatalog-documents/Defense_Brochuresdocuments/Magnetic Literature Application notesdocuments/AN212_Handling_of_Sensor_Bridge_Offset.pdf.

3. Battini, F., Tonarelli, M. Fanucci, L., De Marinis, M.; Giambastiani, A. Experiencing with AMR sensor conditioning in automotive field // Research in Microelectronics and Electronics Conference, 2007. - P. 205-208.

4. Xisheng L., Ruiqing K., Yanxia L., Zhihua W., Xiongying S., Jinhui L. Sensitivity Online Recognition of AMR Sensor // Proceedings of the 2010 IEEE International Conference on Information and Automation. - Harbin, China, 2010. - P. 956-959.

5. Ripka P, Janošek, Butta M. Crossfield Sensitivity in AMR Sensors // IEEE Transactions on Magnetics, 2009. - Vol. 45. - No. 10. - P. 4514-4517.

\section{Markevicius, D. Navikas. Adaptive Thermo-Compensation of Magneto-Resistive Sensor // Electronics and Electrical}

Engineering. - Kaunas: Technologija, 2011. - No. 8(114). - P. 43-46.

There are presented experimental research results of AMR sensors (Honeywell HMC1022, MEMSIC MMC314xMS and STMicroelectronics LSM303DLH) thermo-stability. The experiment results show that not all sensors have temperature characteristics that are declared by manufacturer. Adaptive thermo-compensation algorithm pas proposed. Proposed method avoids need of additional AMR sensors calibration and selection and allows decreasing measurement errors in a wide temperature range (up to $100{ }^{\circ} \mathrm{C}$ ). $\mathrm{Ill} .13$, bibl. 5 (in English; abstracts in English and Lithuanian).

V. Markevičius, D. Navikas. Adaptyvi magnetorezistyvinio jutiklio temperatūrinè kompensacija // Elektronika ir elektrotechnika. - Kaunas: Technologija, 2011. - Nr. 8(114). - P. 43-46.

Pateikti magnetorezistyviniais jutikliais matuojamo lauko komponenčių priklausomybių nuo temperatūros tyrimų rezultatai. Ištirti Honeywell HMC1022, MEMSIC MMC314xMS ir STMicroelectronics LSM303DLH magnetorezistyviniai jutikliai. Nustatyta, kad ne visų jutiklių gamintojų pateikiamos temperatūrinès charakteristikos atitinka realius parametrus. Pasiūlytas adaptyviosios temperatūros poveikio kompensacijos algoritmas. Adaptyvios kompensacijos būdas plačiame temperatūros diapazone (iki $100{ }^{\circ} \mathrm{C}$ ) leidžia išvengti papildomo jutiklių kalibravimo bei atrankos ir padidina magnetorezistyvinių jutiklių matavimo tikslumą. Il. 13, bibl. 5 (anglų kalba; santraukos anglų ir lietuvių k.). 